\title{
Adrenocortical carcinoma in patients with MEN1: a kindred report and review of the literature
}

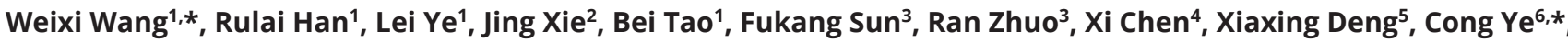 \\ Hongyan Zhao ${ }^{1}$ and Shu Wang ${ }^{1}$ \\ ${ }^{1}$ Shanghai Key Laboratory for Endocrine Tumors, Shanghai Clinical Center for Endocrine and Metabolic Diseases, Shanghai Institute of Endocrine and \\ Metabolic Diseases and Shanghai E-Institute for Endocrinology, Ruijin Hospital, Shanghai Jiaotong University, School of Medicine, Shanghai, China \\ 2Department of Pathology, Ruijin Hospital, Shanghai Jiao Tong University, School of Medicine, Shanghai, China \\ ${ }^{3}$ Department of Urology, Ruijin Hospital, Shanghai Jiao Tong University, School of Medicine, Shanghai, China \\ ${ }^{4}$ Department of General Surgery, Ruijin Hospital, Shanghai Jiaotong University, School of Medicine, Shanghai, China \\ ${ }^{5}$ Pancreatic Disease Centre, Ruijin Hospital, Shanghai Jiao Tong University, School of Medicine, Shanghai, China \\ ${ }^{6}$ Department of Thoracic Surgery, Shanghai Pulmonary Hospital, Tongji University, Shanghai, China
}

Correspondence should be addressed to L Ye: lei_yelei@163.com

*(W Wang and C Ye contributed equally to this work)

\begin{abstract}
Objective: Up to $40 \%$ of multiple endocrine neoplasia type 1 (MEN1) patients may have adrenal cortical tumors. However, adrenocortical carcinoma (ACC) is rare. The clinical manifestations, prevalence, inheritance and prognosis of ACC associated with MEN1 remain unclear. Here we report the clinical manifestations and prevalence of ACC in patients with MEN1.

Design and methods: A retrospective analysis of ACC associated with MEN1 patients at a single tertiary care center from December 2001 to June 2017. Genetic analysis of
Key Words (ACC)
- multiple endocrine neoplasia type 1 (MEN1)

- adrenocortical carcinoma

- TP53

- CTNNB1 MEN1 and other ACC associated genes, loss of heterozygosity (LOH) of MEN1 locus, immunohistochemistry staining of menin, P53 and $\beta$-catenin in ACC tissue were performed.

Results: Two related patients had ACC associated with MEN1. The father had ENSAT stage IV tumor with excessive production of cortisol; the daughter had nonfunctional ENSAT stage I tumor. Both patients carried novel germline heterozygous mutation (c.400_401 insC) of MEN1. The wild-type MEN1 allele was lost in the resected ACC tissue from the daughter with no menin staining. The ACC tissue had nuclear $\beta$-catenin staining, with heterozygous CTNNB1 mutation of 357 del24 and P53 staining in only $20 \%$ cells. Conclusions: ACC associated with MEN1 is rare and may occur in familial aggregates.

\section{Introduction}

Multiple endocrine neoplasia type 1 (MEN1) is an autosomal dominant disease characterized by the presence of endocrine tumors mainly affecting parathyroid, pituitary and pancreatic islet. Adrenal lesions occur in $20-55 \%$ of MEN1 cases and the majority is adrenocortical adenomas or hyperplasia. A small fraction of MEN1 patients developed adrenocortical carcinoma (ACC) $(1,2,3,4,5,6,7,8,9)$. In fact, ACC in general is a rare malignancy with high mortality. Its incidence was 0.7-2.0 cases per million population per year and the overall 5-year survival was only $20-59 \%(10,11)$. However, most previous reports about ACC associated with MEN1 https://ec.bioscientifica.com https://doi.org/10.1530/EC-18-0526 (c) 2019 The authors Published by Bioscientifica Ltd
This work is licensed under a Creative Commons Attribution-NonCommercial-NoDerivatives 4.0 elnternationad ticense ifica . com at 04/26/2023 11:07:40AM 
were case descriptions. The clinical features, prevalence, inheritance and prognosis of ACC associated with MEN1 remain unclear.

The molecular pathogenesis of ACC has been associated with the tumor suppressor gene TP53. An unusually high incidence of ACC has been found in children in southern Brazil and a founder germline mutation in TP53 has been found in 78-97\% of these children (12, 13). In addition, ACC occurred in 3-7\% of adults and $50-80 \%$ of children patients of Li-Fraumeni syndrome, which was caused by germline TP53 mutation (14). WNT/ $\beta$-catenin signaling pathway also plays an important role in sporadic adrenocortical tumorigenesis. Activating point mutations of CTNNB1 have been identified in over $25 \%$ ACCs $(15,16,17,18)$. ENC1 and other $\beta$-catenin target genes were overexpressed in ACCs (19). Coincident $\beta$-catenin activation and TP53 inactivation predicted poor outcome (20). In the recently published TCGA, profiles of ACC, TP53 and CTNNB1 mutations were the most common mutations in ACC, and MEN1 was one of the five significantly mutated genes in ACC. Seven percent of tumors harbored inactivating MEN1 mutations (11), consistent with a prior study identifying recurrent somatic MEN1 mutation in ACC (21). However, the role of MEN1 in ACC tumorigenesis remains to be clarified.

In the current study, we described a MEN1 family with ACC in a cohort of MEN1 patients. Furthermore, we explored the preliminary roles of MEN1 in ACC tumorigenesis and performed a literature review of previously reported cases.

\section{Subjects and methods}

\section{Patient}

We performed a retrospective analysis of a prospectively collected database of MEN1 patients in our institution (Ruijin Hospital, Shanghai Jiaotong University, School of Medicine). This database included consecutive patients diagnosed with MEN1 according to current clinical practice guidelines recommendations (22) from December 2001 to June 2017. Patients were followed up every three months as part of our institutional protocol. The diagnosis of ACC was based on histological samples evaluated by two independent pathologists. We also performed a comprehensive literature search of PubMed, Ovid MEDLINE and Ovid EMBASE for the terms of adrenocortical carcinoma, adrenal lesion, adrenal and multiple endocrine neoplasia type 1 limited to English publication. The last search in this study was updated in June 2017. This study was approved by the Ethics Committee of Ruijin Hospital, Shanghai Jiaotong University, School of Medicine. Consent has been obtained from each patient after full explanation of the purpose and nature of all procedures used.

\section{DNA isolation and sequencing}

Genomic DNA was isolated from peripheral blood sample by using the QIAamp DNA Blood Mini Kit (QIAGEN) and paraffin-embedded tissue by using the QIAamp DNA FFPE Tissue Kit (QIAGEN). Exon 2-10 of the MEN1 gene, coding region of TP53 and exon 3 of CTNNB1 were amplified and analyzed by Sanger sequencing. The primer sequences of MEN1 were previously reported (23), while the primer sequences of coding sequence (CDS) of TP53 and exon 3 of CTNNB1 are listed in Supplementary Table 1 (see section on supplementary data given at the end of this article).

\section{Loss of heterozygosity assay}

Loss of heterozygosity (LOH) analysis was performed using tumor DNA and matched leucocyte DNA. Three short tandem repeat (STR) markers (D11S4946, D11S1983 and D11S4940) were used to determine the region of LOH. MEN1 gene is located between D11S4946 (intragenic in $5^{\prime}$ untranslated region, about $500 \mathrm{bp}$ from MEN1 transcription start site) and D11S1983, transcribing from telomere to centromere. D11S4940 is located approximately $93 \mathrm{~kb} \mathrm{5'}$ of MEN1 gene. The STR markers were amplified by fluorescent carboxyfluorescein (FAM)labeled primers. The PCR products were resolved on an ABI 3730xl sequencer together with GeneScan 500 LIZ as size marker and quantified with GeneMapper v4.0 (Applied Biosystems). Markers were considered informative if two alleles were detected in normal tissue (peripheral blood leucocytes). $\mathrm{LOH}$ is defined as positive if the allele peak ratio is $>1.5$.

\section{Immunohistochemistry}

Formalin-fixed, paraffin wax-embedded tissue was cut into $4 \mu \mathrm{m}$-thick sections. Menin protein was stained by the antimenin antibody from Bethyl Laboratories (A300-105A) at appropriate dilution (1:600), as previously described (24). $\beta$-catenin was stained by $\beta$-catenin antibody from Cell Signaling Technology (9562) at dilution of 1:400. Normal parathyroid tissue was employed as positive control, 
while negative controls were performed by pancreatic neuroendocrine tumors (PNETs) of patient IV:5 (selfcontrol) with known loss expression of menin (somatic sequencing revealed homozygous MEN1 mutation and IHC staining showed absence of menin).

\section{Results}

\section{Patient description}

A total of 121 patients (68 families) were diagnosed as MEN1 from 2001 to 2017 and 33.9\% had adrenal lesion. From those with adrenal lesions, $65.1 \%$ were nonfunctional adenomas, $25.6 \%$ were adenomas with hypercortisolism, $2.3 \%$ were adenomas with aldosteronism, 2.3\% were pheochromocytomas and ACCs account for $4.7 \%$. The median age at the diagnosis of adrenal tumors was 44.5 years (34.3-50.8 years) and a nearly equal sex distribution (male: female $=1.05: 1$ ). Two cases of ACC in the same kindred were found, providing a frequency prevalence of $1.5 \%$ in the overall MEN1 group (the number of MEN1 families with ACC divided by the number of MEN1 families).

The index case was a 51-year-old man (patient III:4) complaining of hypertension and muscle weakness. His hypertension $(150 / 90 \mathrm{mmHg})$ started 8 months ago. Five months later, he started to have edema and weakness of the lower extremities. Hypokalemia $(2.4-3.81 \mathrm{mmol} / \mathrm{L})$ and diabetes (fasting plasma glucose, $10.1 \mathrm{mmol} / \mathrm{L}$ and $\mathrm{HbA} 1 \mathrm{C}, 7.7 \%$ ) was diagnosed by local community hospital. He was prescribed with antihypertensive drugs, potassium supplement and antidiabetic drugs. He had $3 \mathrm{~kg}$ loss during the past eight months. Hypertension and hypopotassium indicated adrenal disease. Physical examination found no sign of Cushing's syndrome. Evaluation of adrenal hormone revealed loss of cortisol rhythm (8:00-16:00-24:00 25.81-25.77-23.82 $\mu \mathrm{g} / \mathrm{dL})$ and elevated urinary free cortisol (UFC) $(1287 \mu \mathrm{g} / 24 \mathrm{~h}$, normal 21-111 $\mu \mathrm{g} / 24 \mathrm{~h}$ ). Overnight dexamethasone suppression test (1 mg ODST) failed to suppress morning cortisol levels $(28.5 \mu \mathrm{g} / \mathrm{dL}$, normal $<5 \mu \mathrm{g} / \mathrm{dL})$. The ODST, in concordance with lower ACTH levels $(8.91 \mathrm{pg} / \mathrm{mL}$, normal 12.00 $78.00 \mathrm{pg} / \mathrm{mL}$ ), indicated adrenal Cushing's syndrome. His aldosterone vertical supine position test was normal. Ultrasound revealed a $14 \mathrm{~cm}$ mass in the left adrenal gland and renal compression. To exclude malignant diseases, we performed abdominal CT, bone scan and ${ }^{18} \mathrm{~F}$-fluorodeoxyglucose positron emission tomographycomputed tomography (FDG-PET/CT). Abdominal CT
(Fig. 1A) showed a left adrenal gland mass (the Hounsfield units was 28 on plain scan and 40 on enhanced CT scan) and multiple pancreatic tumors located in the uncinate process of pancreas and pancreatic duct dilation. Bone scan showed lesions in right third and fifth anterior rib, and left inferior segment of femur. PET/CT scan showed an enormous and irregular left adrenal mass and metastasis to left supraclavicular and mediastinal lymph nodes, bilateral lung and uncinate process of pancreas. In addition, he had incidental finding of hypercalcemia $(2.71-2.79 \mathrm{mmol} / \mathrm{L}$, normal range $2.00-2.75 \mathrm{mmol} / \mathrm{L})$ with hypophosphatemia $(0.45-0.58 \mathrm{mmol} / \mathrm{L}$, normal range $0.80-1.60 \mathrm{mmol} / \mathrm{L}$ ) in the presence of normal serum albumin $(35 \mathrm{~g} / \mathrm{L})$. His 24 -h urinary calcium was high $(8.00 \mathrm{mmol} / 24 \mathrm{~h})$. Serum PTH level was elevated $(270.1 \mathrm{pg} / \mathrm{mL}$, normal range $15.0-68.3 \mathrm{pg} / \mathrm{mL})$ while vitamin $\mathrm{D} \quad\left[25(\mathrm{OH})_{2} \mathrm{D}_{3}\right]$ was normal $(69.54 \mathrm{nmol} / \mathrm{L}$, normal range $>50 \mathrm{nmol} / \mathrm{L}$ ). Both ultrasonography and technetium sestamibi (MIBI) scan (Fig. 1B) revealed bilateral parathyroid adenoma.

Adrenal carcinoma, bilateral parathyroid adenoma and suspected pancreatic tumors suggested MEN1. MRI of pituitary disclosed microadenoma (Fig. 1C) with normal prolactin, growth hormone, thyroid-stimulating hormone, luteinizing hormone, follicule-stimulating hormone, insulin-like growth factor and insulin-like growth factor-binding protein 3. Genetic testing found a hitherto undescribed heterozygous mutation at codon 97 of MEN1 gene, c.400_401insC (Fig. 2A).

He was clinically and genetically diagnosed as MEN1 with hyperparathyroidism, ACC and nonfunctional pituitary adenoma. The staging of ACC according to the European Network for the Study of Adrenal Tumors (ENSAT) classification was stage IV and the 5-year survival was only $18 \%(25,26)$. He received mitotane and succumbed to progressive disease 7 months after diagnosis.

We screened MEN1 c.400_401insC mutation in his kindred and found eight carriers (Fig. 1E). Three family members had been dead of PNETs before genetic screening. The tumor components of his family members are listed in Table 1. The proband is the offspring of a consanguineous marriage. Four of the eight mutation carriers were evaluated for MEN1-related tumors and three members were affected by adrenal tumors. Two of which had adrenocortical adenomas (ACAs) and the proband's daughter was affected with ACC as well (Fig. 1E).

The daughter (patient IV:5) was 27 years old with no complaints. Her blood pressure was $120 / 70 \mathrm{mmHg}$ and had no symptoms or signs of hypercortisolism.

This work is licensed under a Creative Commons Attribution-NonCommercial-NoDerivatives 4.0 Internationab ticense.ifica com at $04 / 26 / 2023$ 11:07:40 
A

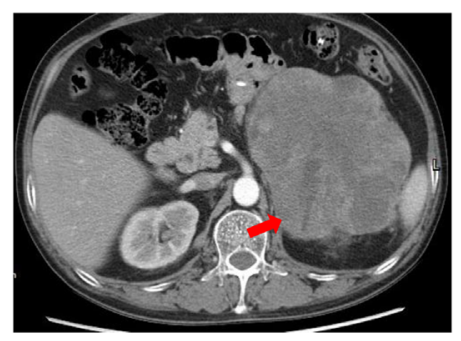

C

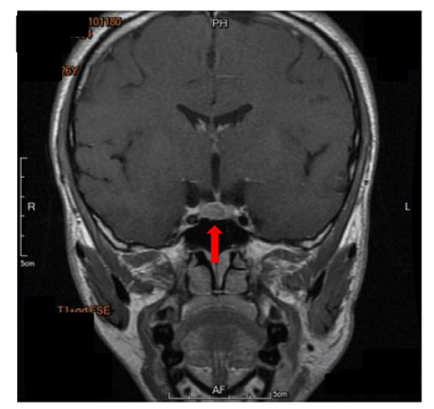

B

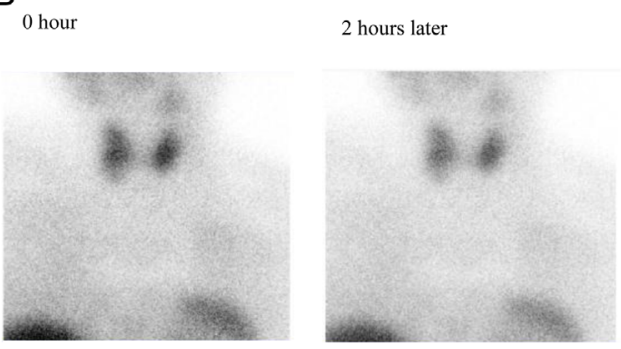

D

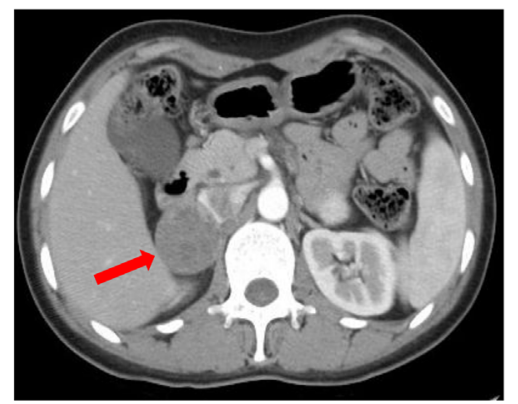

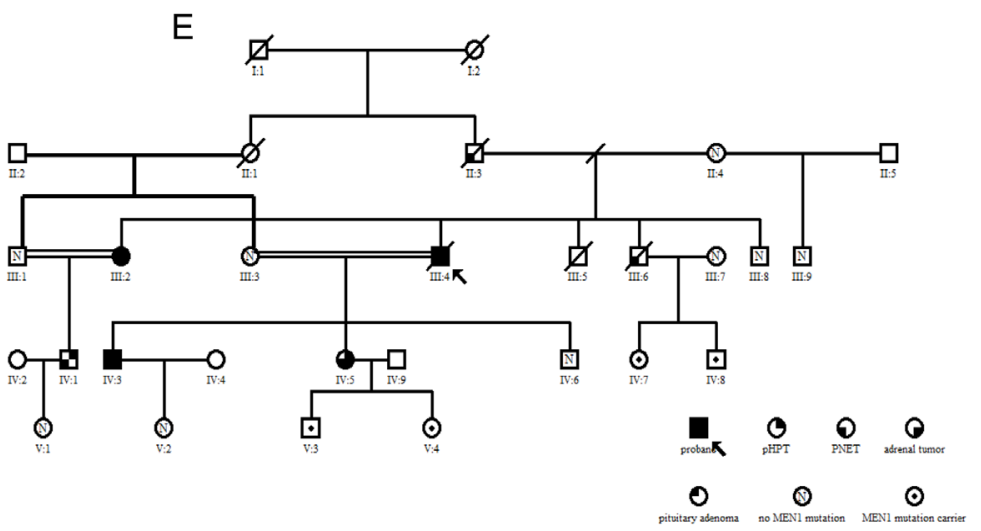

Figure 1

Left adrenal tumor on CT scan (A), bilateral parathyroid adenoma on MIBI (B), pituitary microadenoma on MRI (C) of the proband (III:4). Right adrenal tumor on CT scan of patient IV:5 (D). Pedigree tree (E).
The preoperative imaging investigation included the following: pituitary microadenoma, hyperplasia of the parathyroid glands, a mass in the junction of body and tail of the pancreas $(2.2 \times 3.0 \mathrm{~cm})$ and a mass in the right adrenal gland $(4 \mathrm{~cm} \times 3.7 \mathrm{~cm})$. ACC was considered because of necrosis, hemorrhage and cyst formation on the CT scan (the Hounsfield units was 34.5 on plain scan and 59.1 on enhanced scan, Fig. 1D). Both the cortical and the medulla hormone profiles were normal. Neuron-specific enolase was elevated $(26.29 \mathrm{ng} / \mathrm{mL}$, normal $<17.00 \mathrm{ng} / \mathrm{mL})$. Biochemical measurements revealed elevated serum calcium $(2.72 \mathrm{mmol} / \mathrm{L})$ and PTH levels $(210 \mathrm{pg} / \mathrm{mL})$. Pituitary hormones, gastrin, glucose and insulin levels were normal. She was diagnosed as MEN1 syndrome with primary hyperparathyroidism, nonfunctional pituitary adenoma, nonfunctional PNET and adrenal tumors, possibly malignant. She received laparoscopic right adrenalectomy. The histological findings included the following: round to oval cells, with scant eosinophilic cytoplasm and moderate to marked nuclear pleomorphism, arranged in a loose growth pattern (Fig. 2B); abnormal caryokinesis (>5/50HPF), necrosis and capsular invasion; positive staining of Melan-A, inhibin, CD56, P53 (20\%+) and focal cytokeratins (AE1/AE3). Ki-67 proliferation index was $10 \%$. Melan-A and inhibin are the markers of the adrenocortical origin. The positive staining of these two proteins excluded renal cell carcinoma and other histologically similar tumors (27). The tumor was defined as an adrenocortical carcinoma according to Weiss's criteria with the Weiss score of 7 (on a scale from 0 to 9): high nuclear grade, mitotic rate greater than 5 per 50 high-power fields, atypical mitoses, clear cells comprising $25 \%$ or less of the tumor, diffuse architecture (greater than one-third of the tumor), necrosis and invasion of 
A

Wild type

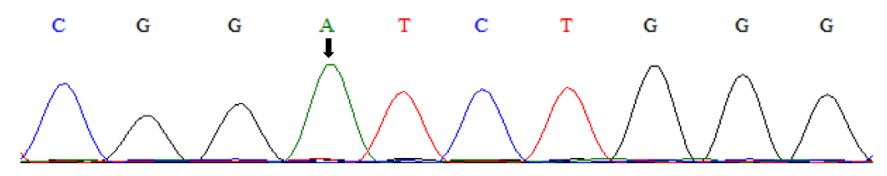

C

Direct sequencing of germline DNA

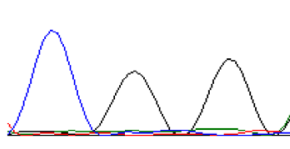

T

T

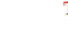

T

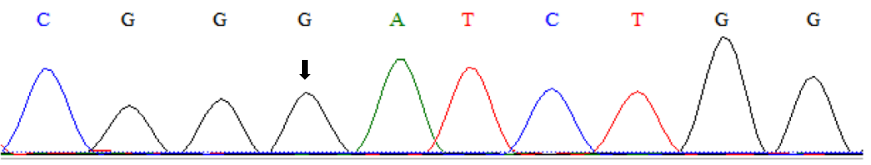

Subclone sequencing

Direct sequencing of

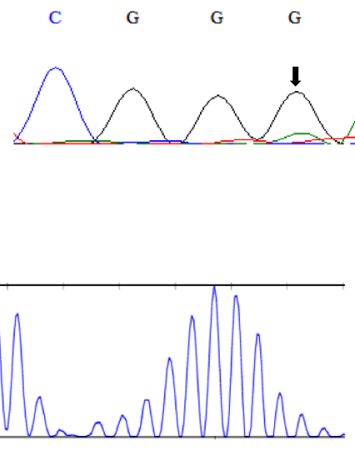

ht 7251

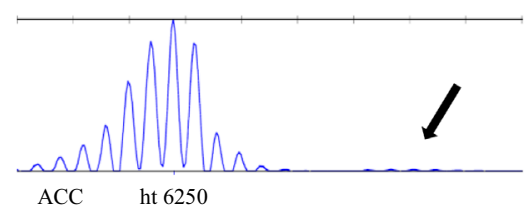

D11S1983

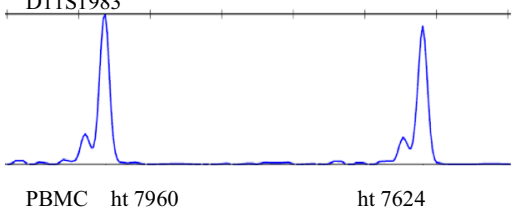

D11S4940

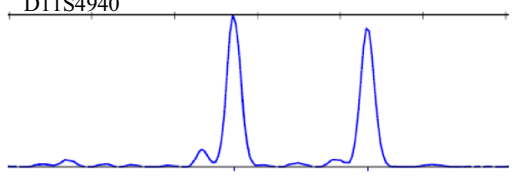

PBMC ht 6829

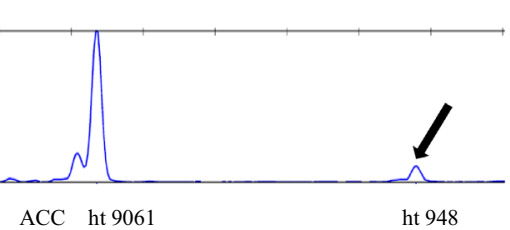

B

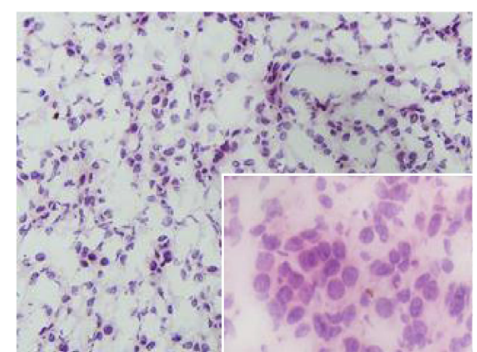

C

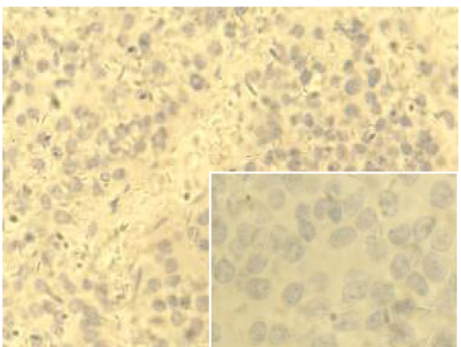

D

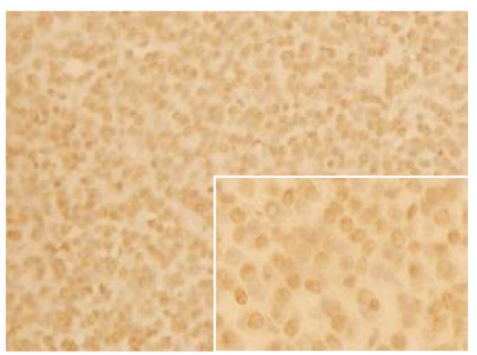

Note: ht, height

\section{Figure 2}

Direct and subclone sequencing of MEN1 with germline DNA from the proband and direct sequencing of MEN1 with somatic DNA from patient IV:5 (A). Hematoxylin and eosin staining of ACC from patient IV:5 (B). Menin absence of ACC tumor from patient IV:5 with menin antibody from Bethyl Laboratories (C) and $\beta$-catenin antibody (D). The amplification is $200 \times$ and $400 \times$, respectively. LOH assay of MEN1 locus (E) in ACC tumor cell from patient IV:5. STR markers D11S4946, D11S1983 and D11S4940 flanking MEN1 gene were displayed respectively. PBMC, peripheral blood mononuclear cells. The arrows indicated allele loss.

capsule of tumor. The presence of three or more criteria correlates with subsequent malignant behavior $(10,28$, 29). Six months later, she received robot-assisted resection of pancreatic body and tail. The tumor was diagnosed as well-differentiated neuroendocrine tumor of the pancreas and grade G1 in histology according to WHO classification 
Table 1 Twelve MEN1 patients in the kindred of MEN1.

\begin{tabular}{|c|c|c|c|c|c|c|c|c|}
\hline ID & Gender & $\begin{array}{l}\text { Age of } \\
\text { onset }^{\text {a }}\end{array}$ & $\begin{array}{l}\text { Age of MEN1 } \\
\text { diagnosis }^{\mathrm{a}}\end{array}$ & $\begin{array}{l}\text { Age of } \\
\text { death }^{\mathrm{a}}\end{array}$ & Tumor component & $\begin{array}{l}\text { Histological } \\
\text { grade }\end{array}$ & Stage & Hormone production \\
\hline III:4 & Male & 50 & 51 & 51 & PHPT, PA & & & \\
\hline \multirow{2}{*}{$\begin{array}{l}\text { The } \\
\text { proband }\end{array}$} & & & & & PNET & NA & & No hormone excess \\
\hline & & & & & $\mathrm{ACC}$ & NA & ENSAT stage: IV & No hormone excess \\
\hline \multirow[t]{3}{*}{ III:2 } & Female & 49 & 54 & Alive & PHPT, PA & & & \\
\hline & & & & & PNET & NA & TNM stage: IA & No hormone excess \\
\hline & & & & & ACA & NA & & No hormone excess \\
\hline \multirow[t]{3}{*}{$\mathrm{IV}: 3$} & Male & 26 & 28 & Alive & PHPT, PA & & & \\
\hline & & & & & PNET & $\mathrm{G} 2$ & TNM stage: IB & No hormone excess \\
\hline & & & & & ACA & Weiss score: 0 & & No hormone excess \\
\hline \multirow[t]{2}{*}{$\mathrm{IV}: 1$} & Male & 30 & 30 & Alive & PHPT & & & \\
\hline & & & & & PNET & NA & TNM stage: IA & No hormone excess \\
\hline \multirow[t]{3}{*}{$\mathrm{IV}: 5$} & Female & 27 & 27 & Alive & PHPT & & & \\
\hline & & & & & PNET & G1 & TNM stage: IB & No hormone excess \\
\hline & & & & & $\mathrm{ACC}$ & Weiss score: 7 & ENSAT stage: I & No hormone excess \\
\hline $\mathrm{IV}: 7$ & Female & No onset & 21 & Alive & & & NA & \\
\hline $\mathrm{IV}: 8$ & Male & No onset & 20 & Alive & & & NA & \\
\hline $\mathrm{V}: 3$ & Male & No onset & 7 & Alive & & & NA & \\
\hline $\mathrm{V}: 4$ & Female & No onset & 4 & Alive & & & NA & \\
\hline $11: 3$ & Male & ND & $\begin{array}{l}\text { Dead before } \\
\text { diagnosis }\end{array}$ & 40 & Malignant PNET & & NA & \\
\hline$\|: 1$ & Female & ND & $\begin{array}{l}\text { Dead before } \\
\text { diagnosis }\end{array}$ & 51 & $\begin{array}{l}\text { Insulinoma? } \\
\text { (hypoglycemia) }\end{array}$ & & NA & $\begin{array}{l}\text { Died of hypoglycemia, } \\
\text { so insulinoma was } \\
\text { suspected }\end{array}$ \\
\hline III:6 & Male & 40 & $\begin{array}{l}\text { Dead before } \\
\text { diagnosis }\end{array}$ & 40 & PNET & & NAs & \\
\hline
\end{tabular}

in 2010 (30), and the TNM stage was IB according to the American Joint Cancer Committee (AJCC) Cancer Staging (31).Currently, patient IV:5 has been followed up for 1 year with no evidence of recurrent or metastatic disease.

The proband's son (patient IV:3) had an ACA in the left adrenal gland and was resected with PNET. The Weiss score of ACA was 0 and PNET was classified as G2 and the TNM stage was IB. Both ACA and PNET were considered as nonfunctional without hormone excess. He was also affected by nonfunctional pituitary microadenoma and primary hyperparathyroidism. The serum calcium was $2.79 \mathrm{mmol} / \mathrm{L}$ (normal range $2.00-2.75 \mathrm{mmol} / \mathrm{L}$ ) and he did not receive surgery for pituitary and parathyroid. The proband's elder sister (patient III:2) had nonfunctional multiple nodular hyperplasia in bilateral adrenal glands. Pancreatic MRI revealed a PNET $(1.5 \times 1.3 \mathrm{~cm})$ in her uncinate process of pancreas (TNM stage: IA) and pituitary MRI showed a microadenoma. She did not receive surgery for the adrenal glands, pancreas and pituitary. Besides, she was diagnosed as primary hyperparathyroidism and received subtotal parathyroidectomy + thymectomy with the pathology of parathyroid hyperplasia (Table 1).

\section{Analysis of MEN1 and other candidate genes in ACC tissue}

ACC tissue was obtained from patient IV:5 during surgery. The resected ACC tissue harbored homogenous frameshift mutation of c.400_401insC in MEN1 gene (Fig. 2A). The resected ACC also showed $\mathrm{LOH}$ of chromosome 11q13, where MEN1 gene was located (Fig. 2E) and menin was negatively stained (Fig. 2C).

We also analyzed the expression and mutation of TP53 and CTNNB1. We found positive $\beta$-catenin staining in the nucleus (Fig. 2D) and P53 staining in only 20\% cells. DNA sequencing revealed a somatic 357 del 24 mutation of CTNNB1 and no mutation in TP53.

\section{Discussion}

In this study, we found ACC can exhibit familial aggregation in MEN1 kindred with novel MEN1 germline mutation. Both alleles of MEN1 gene were damaged in the ACC tissue.
This work is licensed under a Creative Commons Attribution-NonCommercial-NoDerivatives 4.0 enternationad ticense ifica.com at 04/26/2023 11:07:40AM 
By a thorough literature review, we found additional 19 cases of ACC associated with MEN1 from nine reports (Supplementary Table 2) (1, 2, 3, $4,5,6,7,8,9)$. None of the 19 cases were related. To our knowledge, this is the first time a kindred of ACC associated with MEN1 has been reported, proving that ACC can exhibit familial aggregation in MEN1 patients. The pooled prevalence of ACC in MEN1 was 18/1187 (three MEN1-associated ACCs were case reports). The mean and the median age at diagnosis of ACC was 37 and 33 years respectively, younger than sporadic ACC (46-55 years) $(32,33)$. Nonfunctional ACC was found in $7 / 18$ (three cases were not available) of the total cases, similar with sporadic ACC (40\%) (34). Functional ACCs can cause feminization (2/11), virilization (4/11), hypercortisolism (4/11) or both virilization and hypercortisolism (1/11). The median tumor size was $7.5 \mathrm{~cm}(2.8-15.0 \mathrm{~cm})$. Three out of five cases had metastasis. Fourteen patients had germline mutation testing for MEN1 gene and all were positive; 6/14 of the mutation located in exon 2 (Supplementary Table 2). Thirteen patients had follow-up data but two of them were unavailable for the ENSAT stage. All patients with stage I and II diseases survived more than 5 years. All stage IV patients died $(n=3)$ and there were no patients with stage III. Worse prognosis was associated with higher ENSAT stage. Furthermore, worse prognosis was also associated with tumor size larger than $7.5 \mathrm{~cm}$ and diagnostic age older than 33 years. Both groups of patients had median survival time as 0.25 (95\% CI: 0.25 to 3.00) years, while it had not been reached for those $\leq 7.5 \mathrm{~cm}$ or those $\leq 33$ years $(P=0.0025)$. The current guidelines do not recommend regular monitoring of the adrenal glands. We therefore recommended annual evaluation of those with preexisting adrenal lesions, especially for patients younger than 33 years old.

The novel germline frame-shift mutation (c.400_401insC) of MEN1 gene was pathogenic because it segregated with MEN1 phenotype: 8/12 mutation carriers were affected by MEN1-related lesions (primary hyperparathyroidism, PNET or pituitary adenoma), the other four mutation carriers refused evaluation due to young age (IV:7, IV:8, V:3, V:4 were 21, 20, 7, 4 years old, respectively) or lack of symptoms; those without MEN1 mutation were free of MEN1 tumor. The affected ninetyseventh amino acid is located in N-terminal domain (NTD), which is highly conserved in evolution. Menin acts as a scaffold protein, interacting with LEDGF (Lens Epithelium-Derived Growth Factor) and MLL1 on the surface of NTD. Mutations located in NTD would decrease
LEDGF-Menin interaction, therefore diminishing Hoxc8 expression and leading to tumor formation $(35,36)$.

In the current study, we found homozygous mutant MEN1 allele in ACC associated with MEN1 with negative menin protein staining, indicating a possible role of loss function of menin in ACC tumorigenesis. Two major pathways are altered in ACC: $\beta$-catenin pathway and p53/Rb signaling. CTNNB1 (16\%) and TP53 (16\%) were the most common mutant genes (21). About 30\% of $\beta$-catenin-activated transgenic mice developed malignant adrenal tumors by 17-18 months. ACCs were absent from the tumor profile of p53-deficient or mutant mice, possibly due to the different physiology between humans and mice (37). Deletion of exons 8 and 9 of TP53 and a Ser ${ }^{45}$ of CTNNB1 mutation in H295R cells and H193Y mutation of TP53 in SW13 cells has previously been described $(15,38,39)$. Consistently, we found the MEN1associated ACC tissue had nuclear $\beta$-catenin staining, with heterozygosis CTNNB1 mutation of 357del24 and P53 staining in 20\% cells. Based upon these findings, we suggested that additional events such as altered $\beta$-catenin pathway and $\mathrm{p} 53 / \mathrm{Rb}$ signaling may be required for malignant transformation.

In summary, ACC occurs rarely but can exhibit familial aggregation in MEN1 patients. Regular screening strategies should be recommended for MEN1 patients with a family history of ACC, especially for those younger than 33 years and with adrenal lesion.

\section{Supplementary data}

This is linked to the online version of the paper at https://doi.org/10.1530/ EC-18-0526.

\section{Declaration of interest}

The authors declare that there is no conflict of interest that could be perceived as prejudicing the impartiality of the research reported.

\section{Funding}

This study was supported by the grants from National Natural Science Foundation of China $(81570702,81700686,81500604)$ and the National Key Research and Development Program of China (2016YFC0901503).

\section{References}

1 Skogseid B, Larsson C, Lindgren PG, Kvanta E, Rastad J, Theodorsson E, Wide L, Wilander E \& Oberg K. Clinical and genetic features of adrenocortical lesions in multiple endocrine neoplasia type 1. Journal of Clinical Endocrinology and Metabolism 199275 76-81. (https://doi.org/10.1210/jcem.75.1.1352309)

2 Kharb S, Pandit A, Gundgurthi A, Garg MK, Brar KS, Kannan N \& Bharwaj R. Hidden diagnosis of multiple endocrine neoplasia-1 
unraveled during workup of virilization caused by adrenocortical carcinoma. Indian Journal of Endocrinology and Metabolism 201317 514-518. (https://doi.org/10.4103/2230-8210.111672)

3 Griniatsos JE, Dimitriou N, Zilos A, Sakellariou S, Evangelou K, Kamakari S, Korkolopoulou P \& Kaltsas G. Bilateral adrenocortical carcinoma in a patient with multiple endocrine neoplasia type 1 (MEN1) and a novel mutation in the MEN1 gene. World Journal of Surgical Oncology 20119 6. (https://doi.org/10.1186/1477-7819-9-6)

4 Skogseid B, Rastad J, Gobl A, Larsson C, Backlin K, Juhlin C, Akerstrom G \& Oberg K. Adrenal lesion in multiple endocrine neoplasia type 1. Surgery 1995118 1077-1082. (https://doi. org/10.1016/S0039-6060(05)80117-5)

5 Waldmann J, Bartsch DK, Kann PH, Fendrich V, Rothmund M \& Langer P. Adrenal involvement in multiple endocrine neoplasia type 1: results of 7 years prospective screening. Langenbeck's Archives of Surgery 2007392 437-443. (https://doi.org/10.1007/s00423-0060124-7)

6 Langer P, Cupisti K, Bartsch DK, Nies C, Goretzki PE, Rothmund M $\&$ Roher HD. Adrenal involvement in multiple endocrine neoplasia type 1. World Journal of Surgery 200226 891-896. (https://doi. org/10.1007/s00268-002-6492-4)

7 Gatta-Cherifi B, Chabre O, Murat A, Niccoli P, Cardot-Bauters C, Rohmer V, Young J, Delemer B, Du Boullay H, Verger MF, et al. Adrenal involvement in MEN1. Analysis of 715 cases from the Groupe d'etude des Tumeurs Endocrines database. European Journal of Endocrinology 2012166 269-279. (https://doi.org/10.1530/EJE-110679)

8 Haase M, Anlauf M, Schott M, Schinner S, Kaminsky E, Scherbaum WA \& Willenberg HS. A new mutation in the menin gene causes the multiple endocrine neoplasia type 1 syndrome with adrenocortical carcinoma. Endocrine 201139 153-159. (https://doi. org/10.1007/s12020-010-9424-3)

9 Goudet P, Dalac A, Le Bras M, Cardot-Bauters C, Niccoli P, LevyBohbot N, du Boullay H, Bertagna X, Ruszniewski P, Borson-Chazot F, et al. MEN1 disease occurring before 21 years old: a 160-patient cohort study from the Groupe d'etude des Tumeurs Endocrines. Journal of Clinical Endocrinology and Metabolism 2015100 1568-1577. (https://doi.org/10.1210/jc.2014-3659)

10 Fassnacht M, Libe R, Kroiss M \& Allolio B. Adrenocortical carcinoma: a clinician's update. Nature Reviews Endocrinology 20117 323-335. (https://doi.org/10.1038/nrendo.2010.235)

11 Zheng S, Cherniack AD, Dewal N, Moffitt RA, Danilova L, Murray BA, Lerario AM, Else T, Knijnenburg TA, Ciriello G, et al. Comprehensive pan-genomic characterization of adrenocortical carcinoma. Cancer Cell 201630 363. (https://doi.org/10.1016/j.ccell.2016.07.013)

12 Ribeiro RC, Sandrini F, Figueiredo B, Zambetti GP, Michalkiewicz E, Lafferty AR, DeLacerda L, Rabin M, Cadwell C, Sampaio G, et al. An inherited p53 mutation that contributes in a tissue-specific manner to pediatric adrenal cortical carcinoma. PNAS $2001989330-9335$. (https://doi.org/10.1073/pnas.161479898)

13 Pinto EM, Billerbeck AEC, Villares MCBF, Domenice S, Mendonca BB \& Latronico AC. Founder effect for the highly prevalent R337H mutation of tumor suppressor p53 in Brazilian patients with adrenocortical tumors. Arquivos Brasileiros de Endocrinologia and Metabologia 200448 647-650. (https://doi.org/10.1590/S000427302004000500009)

14 Else T, Kim AC, Sabolch A, Raymond VM, Kandathil A, Caoili EM, Jolly S, Miller BS, Giordano TJ \& Hammer GD. Adrenocortical carcinoma. Endocrine Reviews 201435 282-326. (https://doi. org/10.1210/er.2013-1029)

15 Tissier F, Cavard C, Groussin L, Perlemoine K, Fumey G, Hagnere AM, Rene-Corail F, Jullian E, Gicquel C, Bertagna X, et al. Mutations of beta-catenin in adrenocortical tumors: activation of the Wnt signaling pathway is a frequent event in both benign and malignant adrenocortical tumors. Cancer Research 200565 7622-7627. (https:// doi.org/10.1158/0008-5472.CAN-05-0593)
16 Gaujoux S, Tissier F, Groussin L, Libe R, Ragazzon B, Launay P, Audebourg A, Dousset B, Bertagna X \& Bertherat J. Wnt/beta-catenin and 3 ',5'-cyclic adenosine 5'-monophosphate/protein kinase A signaling pathways alterations and somatic beta-catenin gene mutations in the progression of adrenocortical tumors. Journal of Clinical Endocrinology and Metabolism 200893 4135-4140. (https:// doi.org/10.1210/jc.2008-0631)

17 Tadjine M, Lampron A, Ouadi L, Horvath A, Stratakis CA \& Bourdeau I. Detection of somatic beta-catenin mutations in primary pigmented nodular adrenocortical disease (PPNAD). Clinical Endocrinology 200869 367-373. (https://doi.org/10.1111/j.13652265.2008.03273.x)

18 Tadjine M, Lampron A, Ouadi L \& Bourdeau I. Frequent mutations of beta-catenin gene in sporadic secreting adrenocortical adenomas. Clinical Endocrinology 200868 264-270. (https://doi.org/10.1111/ j.1365-2265.2007.03033.x)

19 Giordano TJ, Thomas DG, Kuick R, Lizyness M, Misek DE, Smith AL, Sanders D, Aljundi RT, Gauger PG, Thompson NW, et al. Distinct transcriptional profiles of adrenocortical tumors uncovered by DNA microarray analysis. American Journal of Pathology 2003162 521-531. (https://doi.org/10.1016/S0002-9440(10)63846-1)

20 Ragazzon B, Libe R, Gaujoux S, Assie G, Fratticci A, Launay P, Clauser E, Bertagna X, Tissier F, de Reynies A, et al. Transcriptome analysis reveals that $\mathrm{p} 53$ and $\{$ beta\}-catenin alterations occur in a group of aggressive adrenocortical cancers. Cancer Research 201070 8276-8281. (https://doi.org/10.1158/0008-5472.CAN-10-2014)

21 Assie G, Letouze E, Fassnacht M, Jouinot A, Luscap W, Barreau O, Omeiri H, Rodriguez S, Perlemoine K, Rene-Corail F, et al. Integrated genomic characterization of adrenocortical carcinoma. Nature Genetics 201446 607-612. (https://doi.org/10.1038/ng.2953)

22 Thakker RV, Newey PJ, Walls GV, Bilezikian J, Dralle H, Ebeling PR, Melmed S, Sakurai A, Tonelli F, Brandi ML, et al. Clinical practice guidelines for multiple endocrine neoplasia type 1 (MEN1). Journal of Clinical Endocrinology and Metabolism 201297 2990-3011. (https:// doi.org/10.1210/jc.2012-1230)

23 Ye L, Wang W, Ospina NS, Jiang L, Christakis I, Lu J, Zhou Y, Zhu W, Cao Y, Wang S, et al. Clinical features and prognosis of thymic neuroendocrine tumours associated with multiple endocrine neoplasia type 1: a single-centre study, systematic review and meta-analysis. Clinical Endocrinology 201787 706-716. (https://doi. org/10.1111/cen.13480)

24 Jiang XH, Lu JL, Cui B, Zhao YJ, Wang WQ, Liu JM, Fang WQ, Cao YN, Ge Y, Zhang CX, et al. MEN1 mutation analysis in Chinese patients with multiple endocrine neoplasia type 1. Endocrine-Related Cancer 200714 1073-1079. (https://doi.org/10.1677/ERC-07-0015)

25 Fassnacht M, Wittekind C \& Allolio B. Current TNM classification systems for adrenocortical carcinoma. Pathologia Europaea 201031 374-378. (https://doi.org/10.1007/s00292-010-1306-1)

26 Lughezzani G, Sun M, Perrotte P, Jeldres C, Alasker A, Isbarn H, Budaus L, Shariat SF, Guazzoni G, Montorsi F, et al. The European Network for the Study of Adrenal Tumors staging system is prognostically superior to the international union against cancerstaging system: a North American validation. European Journal of Cancer 201046 713-719. (https://doi.org/10.1016/j.ejca.2009.12.007)

27 Mondal SK, Dasgupta S, Jain P, Mandal PK \& Sinha SK. Histopathological study of adrenocortical carcinoma with special reference to the Weiss system and TNM staging and the role of immunohistochemistry to differentiate it from renal cell carcinoma. Journal of Cancer Research and Therapeutics 20139 436-441. (https:// doi.org/10.4103/0973-1482.119329)

28 Lau SK \& Weiss LM. The Weiss system for evaluating adrenocortical neoplasms: 25 years later. Human Pathology 200940 757-768. (https://doi.org/10.1016/j.humpath.2009.03.010)

29 Fassnacht M, Kroiss M \& Allolio B. Update in adrenocortical carcinoma. Journal of Clinical Endocrinology and Metabolism 201398 4551-4564. (https://doi.org/10.1210/jc.2013-3020) 
30 Rindi G, Arnold R, Bosman F \& Capella C. Nomenclature and classification of digestive neuroendocrine tumours. In $\mathrm{WHO}$ Classification of Tumours, Pathology and Genetics of Tumours of the Digestive System, 4th ed, pp. 10-12. Eds FT Bosman, F Carneiro, R Hruban, et al. Lyon, France: International Agency for Research on Cancer (IARC) Press, 2010.

31 Amin MB, Greene FL, Edge SB, Compton CC, Gershenwald JE, Brookland RK, Meyer L, Gress DM, Byrd DR \& Winchester DP. The Eighth Edition AJCC Cancer Staging Manual: Continuing to build a bridge from a population-based to a more "personalized" approach to cancer staging. CA: A cancer journal for clinicians 201767 93-99. (https://doi.org/10.3322/caac.21388)

32 Luton JP, Cerdas S, Billaud L, Thomas G, Guilhaume B, Bertagna X, Laudat MH, Louvel A, Chapuis Y, Blondeau P, et al. Clinical features of adrenocortical carcinoma, prognostic factors, and the effect of mitotane therapy. New England Journal of Medicine 1990322 1195-1201. (https://doi.org/10.1056/NEJM199004263221705)

33 Bilimoria KY, Shen WT, Elaraj D, Bentrem DJ, Winchester DJ, Kebebew E \& Sturgeon C. Adrenocortical carcinoma in the United States: treatment utilization and prognostic factors. Cancer $2008 \mathbf{1 1 3}$ 3130-3136. (https://doi.org/10.1002/cncr.23886)

34 Allolio B \& Fassnacht M. Clinical review: adrenocortical carcinoma: clinical update. Journal of Clinical Endocrinology and Metabolism 2006 91 2027-2037. (https://doi.org/10.1210/jc.2005-2639)
35 Hughes CM, Rozenblatt-Rosen O, Milne TA, Copeland TD, Levine SS, Lee JC, Hayes DN, Shanmugam KS, Bhattacharjee A, Biondi CA, et al. Menin associates with a trithorax family histone methyltransferase complex and with the hoxc8 locus. Molecular Cell 200413 587-597. (https://doi.org/10.1016/S10972765(04)00081-4)

36 Matkar S, Thiel A \& Hua X. Menin: a scaffold protein that controls gene expression and cell signaling. Trends in Biochemical Sciences 2013 38 394-402. (https://doi.org/10.1016/j.tibs.2013.05.005)

37 Wasserman JD, Zambetti GP \& Malkin D. Towards an understanding of the role of p53 in adrenocortical carcinogenesis. Molecular and Cellular Endocrinology 2012351 101-110. (https://doi.org/10.1016/j. mce.2011.09.010)

38 Sampaoli C, Cerquetti L, Gawhary RE, Bucci B, Amendola D, Marchese R, Misiti S, Novelli G, Toscano V \& Stigliano A. p53 stabilization induces cell growth inhibition and affects IGF2 pathway in response to radiotherapy in adrenocortical cancer cells. PLoS One 20127 e45129. (https://doi.org/10.1371/journal. pone.0045129)

39 Reincke M, Karl M, Travis WH, Mastorakos G, Allolio B, Linehan HM \& Chrousos GP. p53 mutations in human adrenocortical neoplasms: immunohistochemical and molecular studies. Journal of Clinical Endocrinology and Metabolism 199478 790-794. (https://doi. org/10.1210/jcem.78.3.8126158)

Received in final form 11 December 2018

Accepted 4 February 2019

Accepted Preprint published online 4 February 2019 (c) 2019 The authors Published by Bioscientifica Ltd
This work is licensed under a Creative Commons Attribution-NonCommercial-NoDerivatives 4.0 internationab License.ifica com at $04 / 26 / 2023$ 11:07:40AM 